ORNL/TM-2002/53

Treatment of Perchlorate-Contaminated Groundwater Using Highly-Selective, Regenerable Anion-Exchange Resins at Edwards Air Force Base

\author{
B. $\mathrm{Gu}$ \\ G. M. Brown \\ Y.-K. Ku
}

Environmental Sciences Division

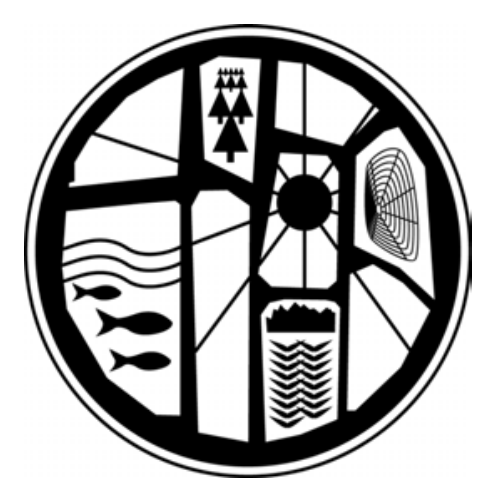




\section{DOCUMENT AVAILABILITY}

Reports produced after January 1, 1996, are generally available free via the U.S. Department of Energy (DOE) Information Bridge.

Web site http://www.osti.gov/bridge

Reports produced before January 1, 1996, may be purchased by members of the public from the following source.

National Technical Information Service

5285 Port Royal Road

Springfield, VA 22161

Telephone 703-605-6000 (1-800-553-6847)

TDD 703-487-4639

Fax 703-605-6900

E-mail info@ntis.fedworld.gov

Web site http://www.ntis.gov/support/ordernowabout.htm

Reports are available to DOE employees, DOE contractors, Energy Technology Data Exchange (ETDE) representatives, and International Nuclear Information System (INIS) representatives from the following source.

Office of Scientific and Technical Information

P.O. Box 62

Oak Ridge, TN 37831

Telephone 865-576-8401

Fax 865-576-5728

E-mail reports@adonis.osti.gov

Web site http://www.osti.gov/contact.html

This report was prepared as an account of work sponsored by an agency of the United States Government. Neither the United States Government nor any agency thereof, nor any of their employees, makes any warranty, express or implied, or assumes any legal liability or responsibility for the accuracy, completeness, or usefulness of any information, apparatus, product, or process disclosed, or represents that its use would not infringe privately owned rights. Reference herein to any specific commercial product, process, or service by trade name, trademark, manufacturer, or otherwise, does not necessarily constitute or imply its endorsement, recommendation, or favoring by the United States Government or any agency thereof. The views and opinions of authors expressed herein do not necessarily state or reflect those of the United States Government or any agency thereof. 
ORNL/TM-2002/53

Environmental Sciences Division

\title{
Treatment of Perchlorate-Contaminated \\ Groundwater Using Highly-Selective, Regenerable Anion-Exchange Resins at Edwards Air Force Base
}

\author{
B. $\mathbf{G u}$ \\ Environmental Sciences Division \\ Oak Ridge National Laboratory \\ G. M. Brown \\ Chemical and Analytical Sciences Division \\ Oak Ridge National Laboratory \\ Y. $-\mathbf{K} . \mathbf{K u}$ \\ Oak Ridge Institute of Science and Education \\ Oak Ridge, Tennessee
}

Date Published: May 2003

\author{
Prepared by \\ OAK RIDGE NATIONAL LABORATORY \\ Oak Ridge, Tennessee 37831 \\ managed by \\ UT-BATTELLE, LLC \\ for the \\ U.S. DEPARTMENT OF ENERGY \\ under contract DE-AC05-00OR22725
}




\section{CONTENTS}

LIST OF FIGURES

$\mathrm{V}$

LIST OF TABLES

vii

ACKNOWLEDGMENT.

ix

EXECUTIVE SUMMARY

xi

1. BACKGROUND

1

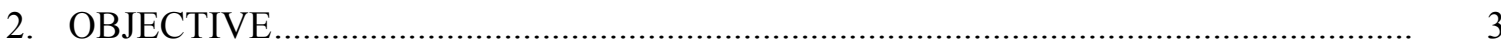

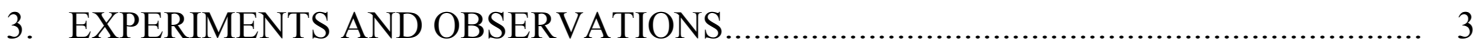

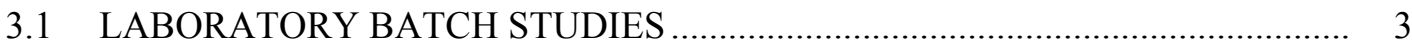

3.2 LABORATORY COLUMN EXPERIMENT …............................................ 5

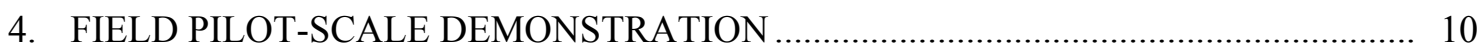

4.1 INITIAL GROUNDWATER TREATMENT …............................................... 10

4.2 REGENERATION OF RESIN COLUMNS …..................................................... 15

4.3 RE-EVALUATION OF RESIN PERFORMANCE

AND REGENERATION ............................................................................... 15

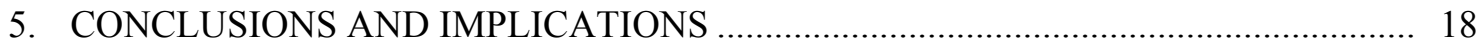

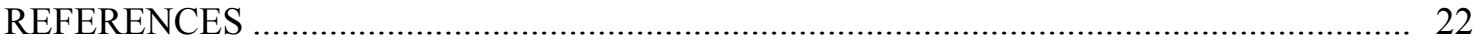




\section{LIST OF FIGURES}

Figure

1 Breakthrough of $\mathrm{ClO}_{4}^{-}$on the Purolite D-3696 resin columns using site groundwater \#196 and \#286 from Edwards AFB. Note: $\mathrm{C} / \mathrm{C}_{0}$ is the ratio of effluent $\mathrm{ClO}_{4}{ }^{-}$concentration to the initial $\mathrm{ClO}_{4}{ }^{-}$concentration in the influent water

2 Desorption of $\mathrm{ClO}_{4}{ }^{-}$from the Purolite D-3696 resin bed by displacement with $\mathbf{F e C l}_{4}^{-}$. Note that the resin bed was first treated with groundwater contaminated with $\mathrm{ClO}_{4}^{-}$from Edwards AFB.

3 Performance of the regenerated Purolite D-3696 resin column (solid square) after it was used for site groundwater treatment (as shown in Figure 1). Note: $\mathrm{C} / \mathrm{C}_{0}$ is the ratio of effluent $\mathrm{ClO}_{4}{ }^{-}$concentration to the initial $\mathrm{ClO}_{4}{ }^{-}$ concentration in the influent water.

$4 \quad$ Resin column assembly and flow diagram used for the pilot-scale field Experiment at Edwards AFB. Column 1 was packed with the Purolite bifunctional D-3696 resin and the column 2 was packed with the monofunctional A-520E resin. The column dimensions were 2 " in diameter and $\sim 11.5$ " in depth, and the flow rate was set at approximately $500 \mathrm{~mL} / \mathrm{min}$ per column. The influent perchlorate concentration in groundwater was $\sim 400 \mu \mathrm{g} / \mathrm{L}$ throughout the experiment. A polishing column was used to ensure perchlorate capture before discharging the treated water.

5 Breakthrough curves of perchlorate in both the monofunctional (M) and bifunctional (B) resin columns used for groundwater treatment at Edwards AFB. Note: B-1 and B-2 refer to the breakthroughs at the middle and outlet ports of thebifunctional resin bed. Perchlorate breakthrough on the polish column was also plotted

6 Fouled resin columns (A and B) as a result of excessive iron oxide precipitation and/or deposition (from the Baker tank) and bio-fouling. Column $\mathrm{C}$ was used in the second run, showing a much lower degree of fouling (used a $1-\mu \mathrm{m}$ in-line filter)

7 Perchlorate elution profiles during the regeneration of the bifunctional (D-3696) and monofunctional (A-520E) resin columns used for the pilot-scale field experiment at Edwards AFB 
8 Breakthrough curves of perchlorate in both the monofunctional (M) and bifunctional (B) resin columns before and after regeneration $(\mathrm{R})$. FB refers to the breakthrough of perchlorate in the fresh bifunctional resin column (without fouling) .....

9 Perchlorate elution profiles during the regeneration of the unfouled bifunctional resin bed and the second regeneration of the monofunctional resin bed. The dotted lines show the regeneration of those fouled columns for comparison (from Figure 7) 


\section{LIST OF TABLES}

$\begin{array}{lll}\text { Table } & \text { Page }\end{array}$

1 Comparison of perchlorate treatment technologies for groundwater remediation...... 2

2 General properties of groundwater from sites \#196 and \#286 at Edwards AFB ........ 4

3 Distribution coefficients $\left(K_{d}\right)^{1}$ of $\mathrm{ClO}_{4}{ }^{-}$on synthetic resins using groundwater from Edwards AFB (\#196) ................................................................................. 5

4 General properties of groundwater obtained at the inlet of the treatment system (Sampling port WSP 1) from Monitoring well 286 at Edwards AFB

5 General properties of groundwater obtained at the inlet of the treatment system (Sampling port WSP 1) from Monitoring well 286 at Edwards AFB

6 Analysis of the composite $\mathrm{FeCl}_{3}-\mathrm{HCl}$ regenerant and dilute $\mathrm{HCl}$ washing solutions used for the regeneration of the bifunctional D-3696 resin bed 



\section{ACKNOWLEDGMENT}

Funding for this work was provided by the Environmental Management Restoration Branch at Edwards Air Force Base, California, through a cooperative Memorandum of Understanding with BWXT Y-12, L.L.C. We are grateful to Robert Wood, Paul Schiff, James A. Specht, and Claudia Domingo for their support throughout this project. We also appreciate the support and program management by David Campbell at BWXT Y-12 and the field technical support provided by Todd Battey, Andrew J. Shepard, and Tom Munoz at Earth Tech, California 


\section{EXECUTIVE SUMMARY}

Selective ion exchange is one of the most effective treatment technologies for removing low levels of perchlorate $\left(\mathrm{ClO}_{4}^{-}\right)$from contaminated water because of its high efficiency without adverse impacts on the water quality caused by adding or removing any chemicals or nutrients. This report summarizes both the laboratory and a field pilot-scale studies to determine the ability and efficiency of the bifunctional synthetic resins to remove $\mathrm{ClO}_{4}{ }^{-}$from the contaminated groundwater at the Edwards Air Force Base in California. Regeneration of the resins after groundwater treatment was also evaluated using the $\mathrm{FeCl}_{3}-\mathrm{HCl}$ regeneration technique recently developed at Oak Ridge National Laboratory. On the basis of this study, the bifunctional resin, D-3696 (made by Purolite, Inc.) was found to be highly selective toward $\mathrm{ClO}_{4}{ }^{-}$and performed much better than one of the best commercial nitrate-selective resins (Purolite A-520E) and more than an order of magnitude better than the Purolite A-500 resin (with a relatively low selectivity). At an influent concentration of $\sim 450 \mu \mathrm{g} / \mathrm{L} \mathrm{ClO}_{4}{ }^{-}$in groundwater, the bifunctional resin bed treated $\sim 40,000$ empty bed volumes of groundwater before a significant breakthrough of $\mathrm{ClO}_{4}{ }^{-}$ occurred. The presence of relatively high concentrations of chloride and sulfate in site groundwater did not appear to affect the ability of the bifunctional resin to remove $\mathrm{ClO}_{4}{ }^{-}$. However, the presence of high iron or iron oxyhydroxides and/or biomass in groundwater caused a significant fouling of the resin beds and greatly influenced the effectiveness in regenerating the resins sorbed with $\mathrm{ClO}_{4}{ }^{-}$. Under such circumstances, a prefilter $(\sim 0.5-1 \mu \mathrm{m})$ was found to be necessary to remove these particulates and to reduce the risk of fouling of the resin beds. Without significant fouling, the resin bed could be effectively regenerated by the $\mathrm{FeCl}_{3}$ displacement technique. Nearly $100 \%$ of the sorbed $\mathrm{ClO}_{4}{ }^{-}$was displaced or recovered after elution with only $\sim 2-5$ bed volumes of the $\mathrm{FeCl}_{3}-\mathrm{HCl}$ regenerant solution. On the basis of both the laboratory and field pilot-scale studies, we therefore anticipate that a combination of the selective ion exchange and the $\mathrm{FeCl}_{3}$-regeneration technologies may offer a cost-effective means to remove $\mathrm{ClO}_{4}{ }^{-}$from contaminated groundwater with significantly reduced waste generation and operational cost. 



\section{BACKGROUND}

The perchlorate anion $\left(\mathrm{ClO}_{4}{ }^{-}\right)$originates as a contaminant in the environment from the disposal of solid salts of ammonium, potassium, or sodium perchlorate. These salts are very soluble in water. The perchlorate anion, although thermodynamically a strong oxidizing agent, is known to be kinetically inert in many redox reactions and noncomplexing in its interactions with typical metal ions found in the environment. These properties make the perchlorate ion exceedingly mobile in the subsurface soil environment. It can persist for many decades under typical groundwater and surface water conditions, due to its kinetic barriers in its reactivity with other organic or inorganic constituents.

Ammonium perchlorate is manufactured for use as a constituent in solid propellants for rockets, missiles, and fireworks. Because of problems with its shelf life, perchlorate-containing propellants must be periodically washed out of the missile and rocket inventory and replaced with a fresh supply. Thus, large volumes of perchlorate-containing compounds have been disposed of in the environment since the 1950's. The presence of this material in the environment poses a threat to ecological receptors and whole ecosystems, either by direct harm to organisms, or by indirectly affecting their ability to survive and reproduce (Urbansky, 1998; Damian and Pontius, 1999). The primary effect of perchlorate on humans is thought to be a decrease in thyroid hormone output due to a competition between perchlorate and iodide sorption in the thyroid

gland. Consequently, the California Department of Health Services has set a provisional action level of $18 \mathrm{ppb}($ or $\mu \mathrm{g} / \mathrm{L})$ for $\mathrm{ClO}_{4}^{-}$in groundwater.

Various treatment technologies are being developed for the removal of $\mathrm{ClO}_{4}{ }^{-}$from contaminated groundwater or surface water. These include ion exchange, bioremediation, reverse osmosis or membrane-based technologies, chemical precipitation, and catalytic chemical or electrochemical reduction. Each of these technologies has relative advantages and disadvantages as summarized in Table 1.

Oak Ridge National Laboratory (ORNL) recently developed a new class of anion-exchange resins that have a bias for the sorption of large, poorly hydrated anions such as $\mathrm{ClO}_{4}{ }^{-}$from contaminated groundwater (Gu et al., 2000a; Brown et al., 2000). These resins are called "bifunctional" anionexchange resins because they have two quaternary ammonium groups: the first has long alkyl chains for higher selectivity, and the second has shorter alkyl chains for improved reaction kinetics. Treatment by ion exchange using these highly-selective anion exchange resins is one of the most promising methods for removing $\mathrm{ClO}_{4}{ }^{-}$at low concentration levels (Gu et al., 2000a,b; Brown et al., 2000; Bonnesen et al., 2000; Venkatesh et al., 2000; Tripp and Clifford, 2000; Batista et al., 2000). In addition to successful benchscale demonstrations, a recent field experiment showed that one bifunctional resin bed (Purolite D-3696) was able to treat more than 100,000 bed volumes of groundwater before a significant breakthrough of $\mathrm{ClO}_{4}{ }^{-}$occurred (with an initial $\mathrm{ClO}_{4}{ }^{-}$concentration of $\sim 50 \mu \mathrm{g} / \mathrm{L}$ ) (Gu et al., 2000a). By comparison, conventional monofunctional resins are usually only effective for treatment of a few hundreds of bed volumes. Additional advantages of using selective ion-exchange include: (1) the treatment process does not change the water chemistry by adding or removing chemicals or nutrients because of its high selectivity towards $\mathrm{ClO}_{4}{ }^{-}$anions, and (2) only a small and simple treatment unit is needed because the system can be operated at a relatively high flow rate, typically at $\sim 0.5-2$ bed volumes per minute. 
Table 1. Comparison of perchlorate treatment technologies for groundwater remediation

\begin{tabular}{|c|c|c|}
\hline & Advantages & Disadvantages \\
\hline $\begin{array}{l}\text { Conventional ion } \\
\text { exchange } \\
\text { (non-selective } \\
\text { resins) }\end{array}$ & $\begin{array}{l}\text { - Practical and economical. } \\
\text { - Effective and able to remove } \mathrm{ClO}_{4}^{-} \\
\text {below detection limit }(<4 \mathrm{ppb}) \text {. } \\
\text { - Fast reaction and simple operation. } \\
\text { - Can be operated at a high flow rate. }\end{array}$ & $\begin{array}{l}\text { - Competition by other anions (e.g., } \\
\mathrm{Cl}^{-}, \mathrm{NO}_{3}^{-}, \mathrm{SO}_{4}=, \mathrm{HCO}_{3}^{-} \text {). } \\
\text { - Large quantities of brine needed } \\
\text { for regeneration. } \\
\text { - Remineralization may be needed. }\end{array}$ \\
\hline $\begin{array}{l}\text { Selective ion } \\
\text { exchange }\end{array}$ & $\begin{array}{l}\text { Efficient and able to remove } \mathrm{ClO}_{4}^{-} \\
\text {below detection limit }(<<4 \mathrm{ppb}) \text {. } \\
\text { - No changes in groundwater chemistry, } \\
\text { and no remineralization is needed. } \\
\text { - Only a small treatment unit is needed, } \\
\text { and it can be operated at a high flow rate } \\
\text { because of its fast reaction. } \\
\text { - Low O\&M with long resin } \\
\text { life(unattended operation)Long waste } \\
\text { disposal costs with low volume waste } \\
\text { generation.Simple system; practical and } \\
\text { economical }\end{array}$ & $\begin{array}{l}\text { Relatively high cost of resins } \\
\text { (depending on production } \\
\text { quantity). } \\
\text { - Slower regeneration process }(\sim 2-5 \\
\text { days). This is offset by the } \\
\text { dramatic increase in resin life } \\
\text { during the treatment phase. }\end{array}$ \\
\hline $\begin{array}{l}\text { Bioremediation } \\
\text { technology }\end{array}$ & $\begin{array}{l}\text { - Practical and economical. } \\
\text { Effective for treatment at relatively high } \\
\text { concentrations (e.g., above } 10 \mathrm{mg} / \mathrm{L} \text { ). }\end{array}$ & $\begin{array}{l}\text { - Need a highly reducing } \\
\text { environment and a continual feed } \\
\text { of nutrients. } \\
\text { - Competition by other electron } \\
\text { acceptors in groundwater and soil. } \\
\text { - Not suitable for treatment of water } \\
\text { plumes with low concentrations of } \\
\text { ClO4- (e.g., }<2 \mathrm{mg} / \mathrm{L} \text { ). } \\
\text { - Slow reactions, or a large treatment } \\
\text { unit is required at the same flow } \\
\text { rate. } \\
\text { - Microorganisms may be } \\
\text { pathogenic or toxic; Requires post- } \\
\text { treatment. }\end{array}$ \\
\hline Reverse osmosis & - Can be effective. & $\begin{array}{l}\text { - Fouling of the membranes. } \\
\text { - Remineralization may be needed. } \\
\text { - High capital cost and impractical } \\
\text { for large-scale applications. }\end{array}$ \\
\hline $\begin{array}{l}\text { Catalytic } \\
\text { chemical } \\
\text { reduction }\end{array}$ & $\begin{array}{l}\text { May work well with highly concentrated } \\
\text { ClO4- in a small volume. }\end{array}$ & $\begin{array}{l}\text { - Relatively slow reduction process. } \\
\text { - May generate toxic byproducts. } \\
\text { - Impractical for large-scale } \\
\text { treatment. }\end{array}$ \\
\hline $\begin{array}{l}\text { Chemical } \\
\text { precipitation }\end{array}$ & $\begin{array}{l}\text { - May work well with high concentrations } \\
\text { of } \mathrm{ClO}_{4} \text { - in a small volume. } \\
\text { - Fast reactions }\end{array}$ & $\begin{array}{l}\text { - Addition of expensive, toxic } \\
\text { chemicals (e.g., nitron). } \\
\text { - Impractical for large-scale } \\
\text { treatment. }\end{array}$ \\
\hline
\end{tabular}


Additionally, ORNL recently developed a novel methodology for regenerating the bifunctional resins and other selective anion-exchange resins that are used for $\mathrm{ClO}_{4}{ }^{-}$sorption. The new regeneration process uses a sequential chemical displacement with ferric chloride dissolved in hydrochloric acid followed by washing with dilute $\mathrm{HCl}$ (patent pending). The new regeneration technique is efficient and cost effective in comparison with conventional brine regeneration. In laboratory tests, less than five bed volumes of the regenerant solution was found to be necessary to recover nearly $100 \%$ of sorbed $\mathrm{ClO}_{4}{ }^{-}$in the resin bed. The regeneration process thus generates minimal amounts of secondary wastes $(<0.05 \%$ of treated groundwater $)$. It is anticipated that a combination of the new resin and the new regeneration methodology may offer a promising solution for remediating groundwater or surface water contaminated with $\mathrm{ClO}_{4}{ }^{-}$.

\section{OBJECTIVES}

The overall objective of this project was to evaluate and demonstrate the use of the ORNLdeveloped bifunctional resin and its regeneration technology to remove $\mathrm{ClO}_{4}{ }^{-}$from contaminated groundwater at Edwards Air Force Base (AFB). The work plan included an initial laboratory evaluation using the site groundwater and was followed by a small-scale field evaluation at the Edwards AFB site. This report summarizes the results from both the initial laboratory studies and the pilot-scale field treatability study for evaluation of resin selectivity, capacity, and regeneration effectiveness using groundwater drawn directly from site wells.

\section{EXPERIMENTS AND OBSERVATIONS}

\subsection{LABORATORY BATCH STUDIES}

As stated above, initial laboratory experiments were performed to determine the selectivity and sorption capacity of the bifunctional resin (Purolite D-3696) and two commercially available monofunctional resins by using the site groundwater. This experiment was necessary in case the groundwater contained unknown constituents that would interfere with resin performance. Two commercially available monofunctional resins (Purolite A-520E and Purolite A-500) were used to establish baseline for comparison of resin performance and costs. Our previous studies have shown that the Purolite A-520E resin was one of the best commercially available resins with respect to perchlorate removal. The Purolite A-500 resin is functionalized with trimethyl functional groups with a relatively low selectivity to perchlorate. It is a low-cost resin but still performs much better than those non-selective Type II resins.

A total of $\sim 10$ gal of the $\mathrm{ClO}_{4}{ }^{-}$contaminated groundwater was obtained from the Edwards AFB site by Earth Tech personnel ( $\sim 5$ gal each from Sites \#196 and \#286). The groundwater was analyzed immediately after receipt with respect to its $\mathrm{pH}$ and anion composition. Results are summarized in Table 2. In general, the groundwater contained relatively high concentrations of chloride and sulfate, and a relatively high $\mathrm{pH}$ (\#286 in particular), as was expected in water taken from these sites. However, both groundwater samples contained a relatively high concentration 
of $\mathrm{ClO}_{4}^{-}(>5 \mathrm{mg} / \mathrm{L})$, which may be attributed to the fact that the wells were not purged before sampling. On the basis of prior sampling, it was estimated that $\mathrm{ClO}_{4}{ }^{-}$concentration should be stable at around 300-600 $\mu \mathrm{g} / \mathrm{L}$ under a continuous flow-through condition (Earth Tech).

Table 2. General properties of groundwater obtained from sites \#196 and \#286 at Edwards AFB

\begin{tabular}{lcc}
\hline Property & Site \#196 & Site \#286 \\
\hline $\mathbf{H C O}_{3}^{-}(\mathrm{mg} / \mathrm{L})$ & 215 & 130 \\
$\mathbf{B r}^{-}(\mathrm{mg} / \mathrm{L})$ & 0.31 & 0.66 \\
$\mathbf{C l}^{-}(\mathrm{mg} / \mathrm{L})$ & 298 & 312 \\
$\mathbf{N O}_{3}^{-}(\mathrm{mg} / \mathrm{L})$ & 2.8 & 1.9 \\
$\mathbf{S O}_{4}{ }^{-}(\mathrm{mg} / \mathrm{L})$ & 141 & 109 \\
$\mathbf{C l O}_{4}^{-}(\mathrm{mg} / \mathrm{L})$ & $>10$ & 5.8 \\
$\mathbf{P H}$ & 7.2 & 8.7 \\
\hline
\end{tabular}

Another important observation was that the groundwater appeared to be turbid, containing significant amounts of sediments or clay colloidal materials. This may again be attributed to the fact that the wells were not purged before sampling. As a result, the groundwater had to be filtered before commencing the laboratory batch and column flow-through experiments, as will be discussed below.

Batch equilibrium studies were then performed to determine the distribution coefficients and sorption capacity of the bifunctional resin and two commercially available monofunctional resins (Purolite A-520E and Purolite A-500) for comparison. The distribution coefficient for sorption of perchlorate to the resins, $K_{d}$ (in $\mathrm{mL} / \mathrm{g}$ ), was calculated as the ratio of the number of moles of perchlorate (expressed as the mass in $\mathrm{mg}$ ) sorbed per gram of resin divided by the concentration of perchlorate remaining in solution (in $\mathrm{mg} / \mathrm{mL}$ ), i.e.,

$$
K_{d}=\frac{\text { Perchlorate sorbed on resin }(m g / g)}{\text { Perchlorate in solution }(m g / m L)}=\frac{\left(C_{0}-C\right) / m}{C}
$$

where $C_{0}$ and $C$ are the initial and final concentrations $(\mathrm{mg} / \mathrm{mL})$ of $\mathrm{ClO}_{4}{ }^{-}$in solution, and $m$ is the mass of resin per unit volume of test solution ( $\mathrm{Gu}$ et al., 2000a). 
Results are listed in Tables 3 and 4. In general, the new bifunctional resin showed a much better selectivity for sorption of perchlorate from the contaminated groundwater than the Purolite A$520 \mathrm{E}$ and Purolite A-500 resins. These results are similar to what we observed previously (Gu et al., 2000a). Although both groundwater samples contained much higher concentrations of chloride and sulfate, perchlorate ions were selectively removed, particularly by the bifunctional resin (Purolite D-3696). At the 1-h equilibration, more than $99 \%$ of perchlorate was already removed from the solution (with an equilibrium concentration of only $\sim 0.075 \mathrm{mg} / \mathrm{L}$ ), although the initial concentration was adjusted at $10 \mathrm{mg} / \mathrm{L}$.

Table 3. Distribution coefficients $\left(\mathrm{K}_{d}\right)^{1}$ of $\mathrm{ClO}_{4}{ }^{-}$on synthetic resins using groundwater from Edwards AFB (\#196). Experiments were performed with $100 \mathrm{~mL}$ test solution and $0.1 \mathrm{~g}$ dry resin. The initial $\mathrm{ClO}_{4}^{-}$concentration was $\sim 10 \mathrm{mg} / \mathrm{L}$

\begin{tabular}{ccccc}
\hline \multicolumn{1}{c}{ Resin } & $\begin{array}{c}\mathbf{1 ~ h} \boldsymbol{K}_{\boldsymbol{d}} \\
(\mathrm{mL} / \mathrm{g})\end{array}$ & $\begin{array}{c}\mathbf{2 4} \mathbf{~ h} \boldsymbol{K}_{\boldsymbol{d}} \\
(\mathrm{mL} / \mathrm{g})\end{array}$ & $\begin{array}{c}\mathbf{9 6 ~ \mathbf { ~ }} \boldsymbol{K}_{\boldsymbol{d}} \\
(\mathrm{mL} / \mathrm{g})\end{array}$ & $\begin{array}{c}\mathbf{1 6 8} \mathbf{h} \boldsymbol{K}_{\boldsymbol{d}} \\
(\mathrm{mL} / \mathrm{g})\end{array}$ \\
\hline Purolite D-3696 & 131,750 & 698,100 & 883,780 & 971,920 \\
Purolite A-520E & 69,310 & 176,520 & 216,250 & 214,067 \\
Purolite A-500 & 17,630 & 41,570 & 47,670 & 46,900 \\
\hline
\end{tabular}

${ }^{1}$ All $K_{d}$ values have a $\pm 5 \%$ uncertainty.

Table 4. Distribution coefficients $\left(K_{d}\right)^{1}$ of $\mathrm{ClO}_{4}^{-}$on synthetic resins using groundwater from Edwards AFB (\#286). Experiments were performed with $100 \mathrm{~mL}$ test solution and $0.1 \mathrm{~g}$ dry resin. The initial $\mathrm{ClO}_{4}{ }^{-}$concentration was $\sim 10 \mathrm{mg} / \mathrm{L}$

\begin{tabular}{ccccc}
\hline Resin & $\begin{array}{c}\mathbf{1 ~ h} \boldsymbol{K}_{\boldsymbol{d}} \\
(\mathrm{mL} / \mathrm{g})\end{array}$ & $\begin{array}{c}\mathbf{2 4} \mathbf{h} \boldsymbol{K}_{\boldsymbol{d}} \\
(\mathrm{mL} / \mathrm{g})\end{array}$ & $\begin{array}{c}\mathbf{9 6 ~ h} \boldsymbol{K}_{\boldsymbol{d}} \\
(\mathrm{mL} / \mathrm{g})\end{array}$ & $\begin{array}{c}\mathbf{1 6 8} \mathbf{h} \boldsymbol{K}_{\boldsymbol{d}} \\
(\mathrm{mL} / \mathrm{g})\end{array}$ \\
\hline Purolite D-3696 & 133,080 & 778,850 & 826,980 & 935,690 \\
Purolite A-520E & 71,540 & 174,630 & 205,855 & 209,640 \\
Purolite A-500 & $\mathrm{nd}^{2}$ & $\mathrm{nd}$ & $\mathrm{nd}$ & $\mathrm{nd}$ \\
\hline
\end{tabular}

1 All $K_{d}$ values have a $\pm 5 \%$ uncertainty.

2 nd $=$ not determined.

\subsection{LABORATORY COLUMN EXPERIMENT}

Column flow-through experiments were then performed with the bifunctional D-3696 resin to determine the breakthrough of $\mathrm{ClO}_{4}{ }^{-}$in a small column $(10 \times 22 \mathrm{~mm})$ as a function of the number of bed volumes of contaminated groundwater passed through the column. The initial perchlorate 
concentration was adjusted to $10 \mathrm{mg} / \mathrm{L}$, and flow rate was maintained at $30 \mathrm{~mL} / \mathrm{min}$ (or about 17 bed volumes per minute) in order to accelerate the breakthrough experiment in the laboratory. These experimental conditions were intentionally similar to our previous studies using synthetic groundwater to allow comparison of resin performance data with respect to perchlorate removal.

Results are presented in Figure 1. The $\mathrm{ClO}_{4}{ }^{-}$breakthrough in synthetic groundwater from our previous studies also was included in Figure 1 for comparison. The X-axis shows the bed volumes of groundwater passed through the resin column (plotted on a log scale) whereas the $\mathrm{Y}$ axis was plotted as the ratio of effluent $\mathrm{ClO}_{4}{ }^{-}$concentration $(\mathrm{C})$ to the influent concentration $\left(\mathrm{C}_{0}\right)$. Results indicate that all three breakthrough curves virtually overlapped, suggesting that the site groundwater had no adverse impact on the performance of the bifunctional resin. The number of treated bed volumes prior to breakthrough appeared similar whether using different site groundwater samples or the synthetic groundwater from previous studies with varying $\mathrm{pH}$ and anion compositions (Gu et al., 2000a). In all cases, the resin removed a substantial amount of perchlorate with $10 \%$ breakthrough occurring after approximately 2,000 bed volumes of the test groundwater had passed through the column with an initial $\mathrm{ClO}_{4}{ }^{-}$concentration of $10 \mathrm{mg} / \mathrm{L}$. It is pointed out, however, at a lower influent $\mathrm{ClO}_{4}{ }^{-}$concentration (as is commonly observed in groundwater), more bed volumes of groundwater can be treated. For example, at an initial $\mathrm{ClO}_{4}{ }^{-}$ concentration of $\sim 0.05 \mathrm{mg} / \mathrm{L}$, approximately 100,000 bed volumes of groundwater may be treated (Gu et al., 2000a).

After completion of the column flow-through experiment, the resin bed with sorbed $\mathrm{ClO}_{4}{ }^{-}$was subjected to regeneration using the ORNL-developed tetrachloroferrate displacement technique. The displaced $\mathrm{ClO}_{4}{ }^{-}$in the effluent was monitored, and a mass balance obtained for determination of the regeneration efficiency. Results (Figure 2) indicate that the sorbed $\mathrm{ClO}_{4}{ }^{-}$was rapidly displaced by the $\mathrm{FeCl}_{4}{ }^{-}$ions in the regenerant solution composed of only $\mathrm{FeCl}_{3}$ and $\mathrm{HCl}$; nearly $100 \%( \pm 2 \%)$ displacement of $\mathrm{ClO}_{4}{ }^{-}$was achieved after elution with only $\sim 5$ bed volumes of the regenerant solution. Both columns (\#196 and \#286 after perchlorate sorption) performed similarly.

After regeneration, the column (\#196) was subjected to the flow-through experiment again (for sorption of perchlorate) under the same experimental conditions as described above. This was to evaluate the performance of the regenerated resin column for $\mathrm{ClO}_{4}{ }^{-}$sorption. Results were shown in Figure 3. The breakthrough curve (\#196 after regeneration) matched very well with the original breakthrough curves as shown in Figure 1, suggesting that nearly $100 \%$ of the exchange sites on the resin were recovered after regeneration. No apparent deterioration of resin performance was observed. Note that the repeated column breakthrough experiments were performed only with the column \#196 because of the overall similarities between groundwater at sites \#196 and \#286 (as shown in Figure 1). Results of the column studies are also consistent with our previous observations that, even after seven repeated sorption and regeneration cycles, we observed no significant decrease in the resin performance (Gu et al., 2000a).

It is therefore concluded that, on the basis of this initial phase of laboratory experiment, a combination of the bifunctional resin and the new regeneration technology is applicable for site groundwater treatment at Edwards AFB. 


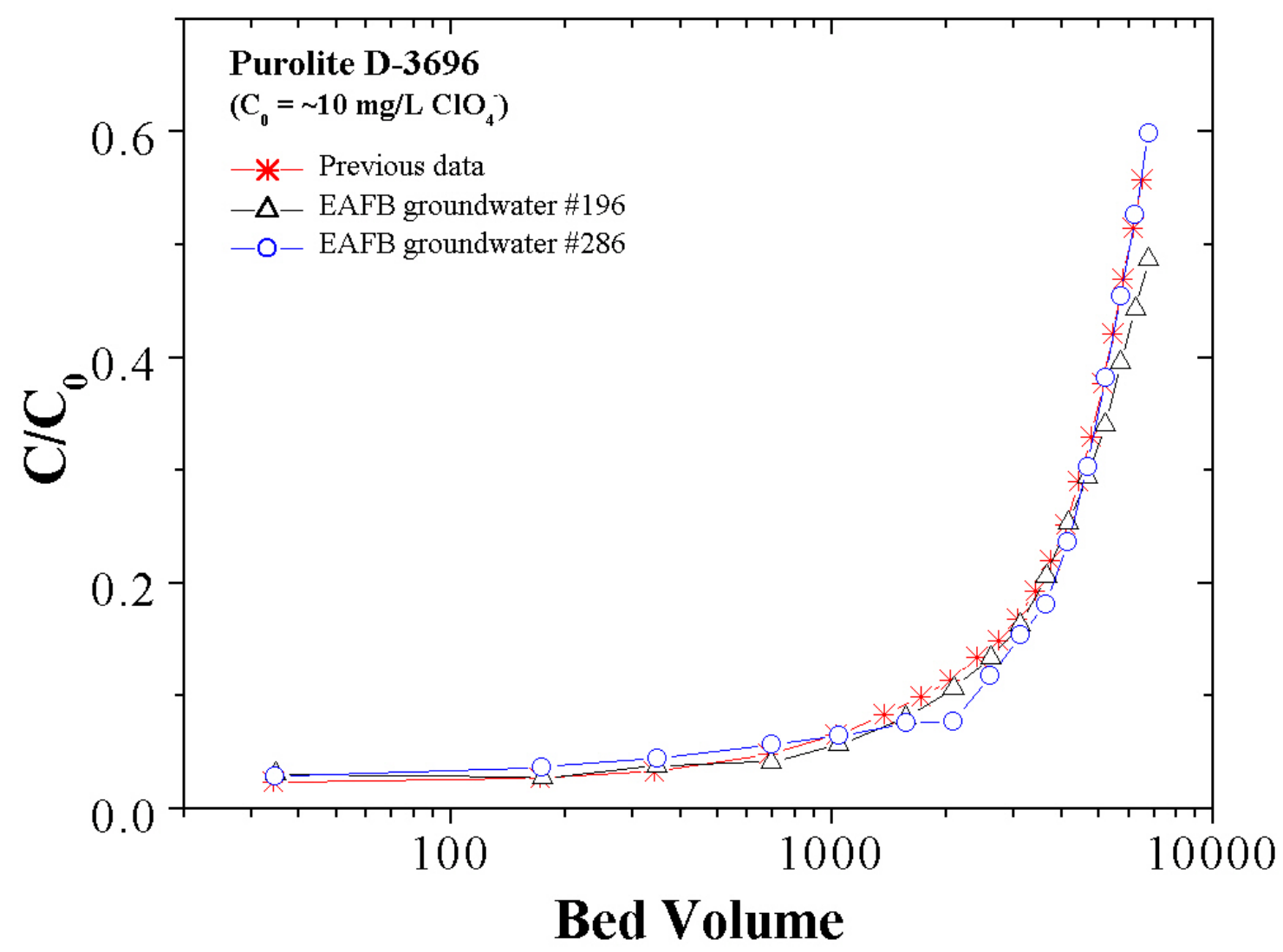

Fig. 1. Breakthrough of $\mathrm{ClO}_{4}^{-}$on the Purolite D-3696 resin columns using site groundwater \#196 and \#286 from Edwards AFB. Note: $\mathrm{C} / \mathrm{C}_{0}$ is the ratio of effluent $\mathrm{ClO}_{4}{ }^{-}$ concentration to the initial $\mathrm{ClO}_{4}{ }^{-}$concentration in the influent water. 


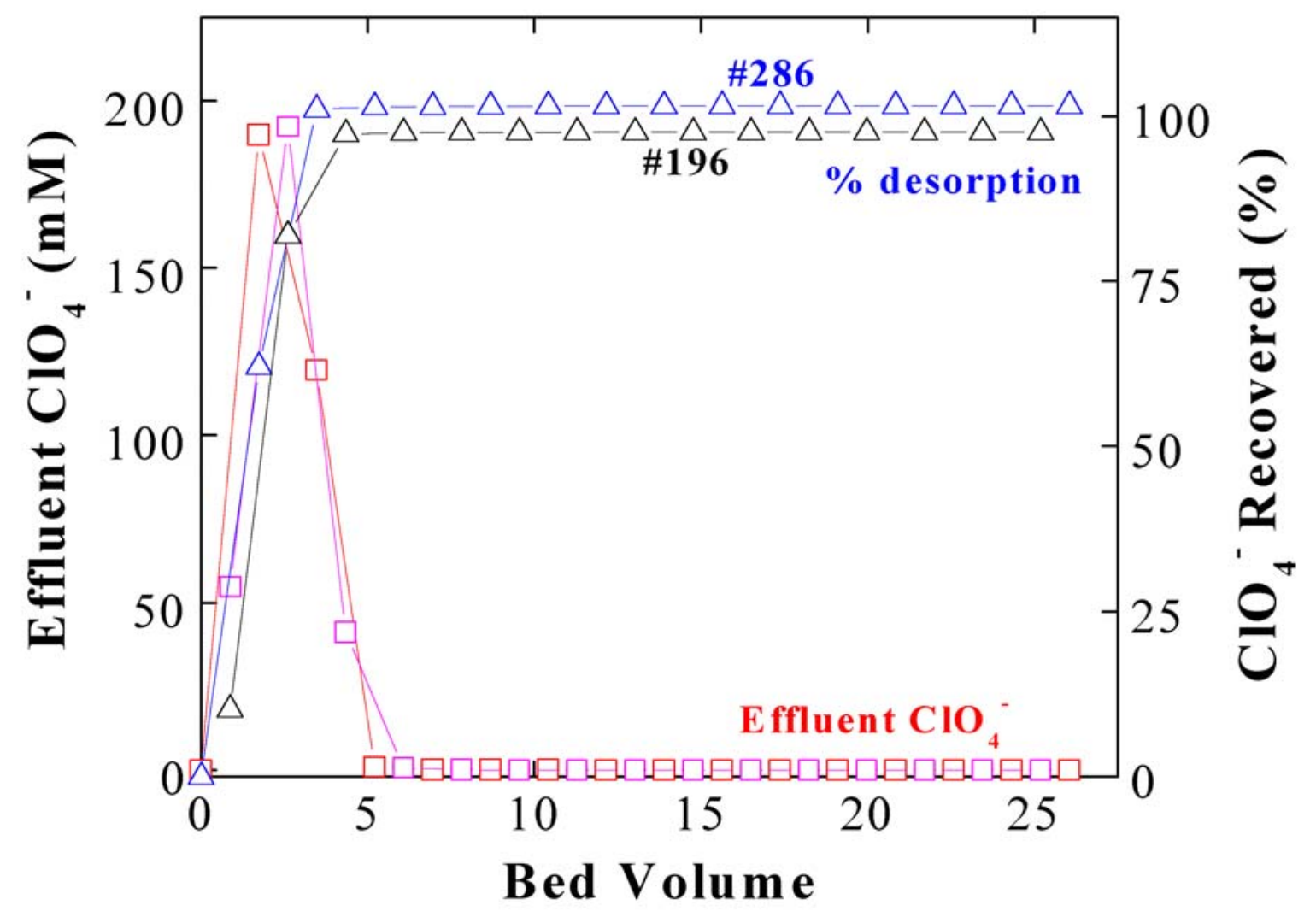

Fig. 2. Desorption of $\mathrm{ClO}_{4}^{-}$from the Purolite D-3696 resin bed by displacement with $\mathrm{FeCl}_{4}{ }^{-}$. Note that the resin bed was first treated with groundwater contaminated with $\mathrm{ClO}_{4}{ }_{4}^{-}$from Edwards AFB. 


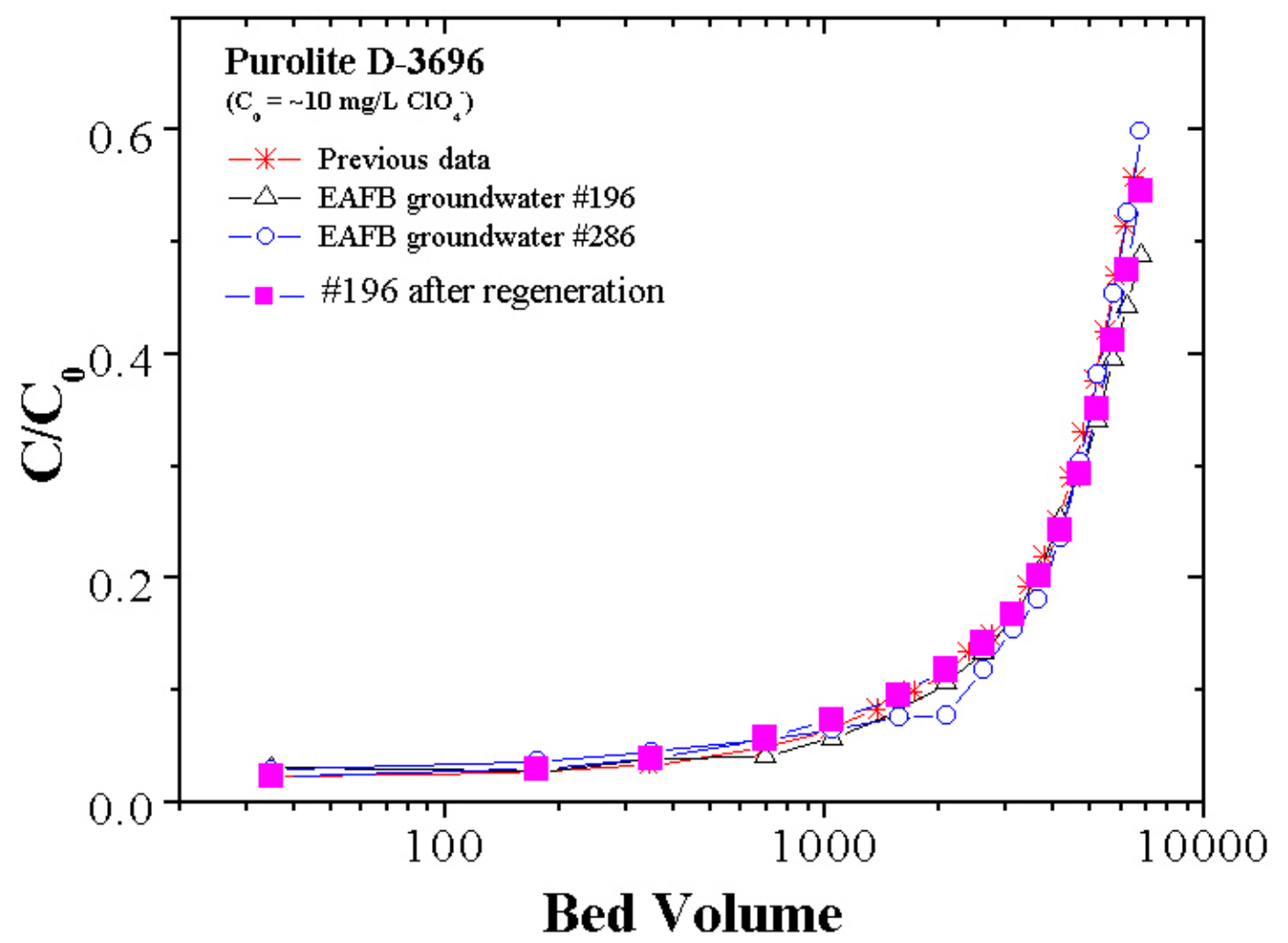

Fig. 3. Performance of the regenerated Purolite D-3696 resin column (solid square) after it was used for site groundwater treatment (as shown in Figure 1). Note: $C / C_{0}$ is the ratio of effluent $\mathrm{ClO}_{4}{ }^{-}$concentration to the initial $\mathrm{ClO}_{4}{ }^{-}$concentration in the influent water. 


\section{FIELD PILOT-SCALE DEMONSTRATION}

\subsection{INITIAL GROUNDWATER TREATMENT}

On the basis of the bench-scale test, a pilot-scale field flow-through experiment was initiated on June 25, 2001, in an attempt to evaluate the performance of the resins before and after regeneration under realistic field conditions. Monitoring well 286 was selected as the source of contaminated groundwater. The general chemical composition and properties of the groundwater are listed in Table 5. A flow diagram of the field experimental configuration is provided in Figure 4. Both the bifunctional (Purolite D-3696) and monofunctional (Purolite A-520E) resins were run in parallel for comparison. The column dimensions were 2 " in diameter and $\sim 11.5$ " in depth, and the flow rate was set at approximately $500 \mathrm{~mL} / \mathrm{min}$ per column (or $\sim 0.89$ bed volumes per minute). A third polishing column was used to capture the residual perchlorate at breakthrough. This ensured that all $\mathrm{ClO}_{4}{ }^{-}$was captured before discharging the treated groundwater. The influent perchlorate concentration in groundwater was $\sim 450 \mu \mathrm{g} / \mathrm{L}$ and varied between $\sim 400$ and $500 \mu \mathrm{g} / \mathrm{L}$ throughout the experiment.

During the initial setup of the pilot scale test, a large Baker tank (20,000 gal.) was used for water collection and provided for influent water accumulation prior to treatment. It was observed that this tank contained some sediment and/or iron oxide particulates from corrosion. While noted, the tank was not flushed prior to test initiation. In addition, clear plastic tubes used to connect the columns to the influent water were noted to accumulate biological growth during the course of the test.

The breakthrough of perchlorate was continuously monitored by the analysis of effluent perchlorate concentration over time. In addition, perchlorate concentration in the middlesampling port of the bifunctional resin column was monitored, and the results are presented in Figure 5. The initial breakthrough of perchlorate at the effluent port on the monofunctional resin column occurred after $\sim 14,000$ bed volumes of groundwater had been treated in about 2 weeks. However, full breakthrough of the perchlorate did not occur until $\sim 35,000$ bed volumes of groundwater had passed through the treatment column. By a mass-balance analysis, it was determined that approximately $3,700 \mathrm{mg}$ of perchlorate was retained by the monofunctional resin column at the initial breakthrough and $\sim 5,400 \mathrm{mg}$ at the full breakthrough.

On the bifunctional resin column, we observed an initial perchlorate breakthrough after passing $\sim 14,000$ bed volumes of groundwater at the mid-sampling port and after $\sim 20,000$ bed volumes at the column effluent. However, a full breakthrough of perchlorate had not occurred after $\sim 56,000$ bed volumes of groundwater had been treated (system shut down). The total amount of perchlorate retained on the bifunctional resin was estimated to be $\sim 10,700 \mathrm{mg}$. The performance of the bifunctional resin therefore appeared only slightly better than that of the monofunctional resin and certainly not as well as anticipated. In particular, the initial perchlorate breakthrough at the bifunctional resin column effluent occurred rapidly (at $\sim 20,000$ bed volumes). It was determined that the primary reason for early breakthrough of perchlorate was biofouling and system clogging because of the precipitation and/or deposition of iron oxyhydroxides in the macroporous resin beads. The fouled resin columns are shown in Figure 6. 
Because of the large capacity of the Baker tank, groundwater was pumped into and stored in the tank (stagnant) before it was pumped through the resin treatment system. In addition, the tank lid was initially left open, providing an excellent environment for the growth of algae and microorganisms. The tank itself was rusty and probably contributed much of the iron particles or precipitates in the resin column, despite the fact that a $15-\mu \mathrm{m}$ in-line filter was used initially between the tank and the resin columns. The system clogging was noticed after a few days of operation and the team was notified. System operation was stopped on the seventh day because of a significantly reduced flow rate and an increased pressure drop. The columns were flushed with diluted chlorine bleach ( $\sim 6 \%$, diluted $1: 15)$, and the in-line filter was changed to $1-\mu \mathrm{m}$ pore size in order to capture most of iron oxide particles in the influent water stream. The treatment system was then brought back on line until full breakthrough of perchlorate was observed in both the bifunctional and monofunctional resin columns.

Table 5. General properties of groundwater obtained at the inlet of the treatment system (Sampling port WSP 1) from monitoring well 286 at Edwards AFB

\begin{tabular}{lccc}
\hline \multicolumn{1}{c}{ Property } & \multicolumn{2}{c}{ Property } \\
\hline $\mathbf{H C O}_{3}^{-}(\mathrm{mg} / \mathrm{L})$ & 226 & $\mathbf{F e}(\mathrm{mg} / \mathrm{L})$ & 0.04 \\
$\mathbf{B r}^{-}(\mathrm{mg} / \mathrm{L})$ & 0.8 & $\mathbf{A l}(\mathrm{mg} / \mathrm{L})$ & 0.05 \\
$\mathbf{C l}^{-}(\mathrm{mg} / \mathrm{L})$ & 356 & $\mathbf{C a}(\mathrm{mg} / \mathrm{L})$ & 21.3 \\
$\mathbf{N O}_{3}^{-}(\mathrm{mg} / \mathrm{L})$ & 0.7 & $\mathbf{M g}(\mathrm{mg} / \mathrm{L})$ & 9.2 \\
$\mathbf{S O}_{4}{ }^{-}(\mathrm{mg} / \mathrm{L})$ & 173 & $\mathbf{C o}(\mathrm{mg} / \mathrm{L})$ & $\mathrm{nd}^{*}$ \\
$\mathbf{C l O}_{4}^{-}(\mu \mathrm{g} / \mathrm{L})$ & 460 & $\mathbf{C d}(\mathrm{mg} / \mathrm{L})$ & $\mathrm{Nd}$ \\
$\mathbf{T O C}^{(\mathrm{mg} / \mathrm{L})}$ & 0.94 & $\mathbf{S i ~}(\mathrm{mg} / \mathrm{L})$ & 14.9 \\
$\mathbf{P H}$ & 8.4 & $\mathbf{M n}(\mathrm{mg} / \mathrm{L})$ & $\mathrm{Nd}$ \\
\hline
\end{tabular}

* nd $=$ not detected. 


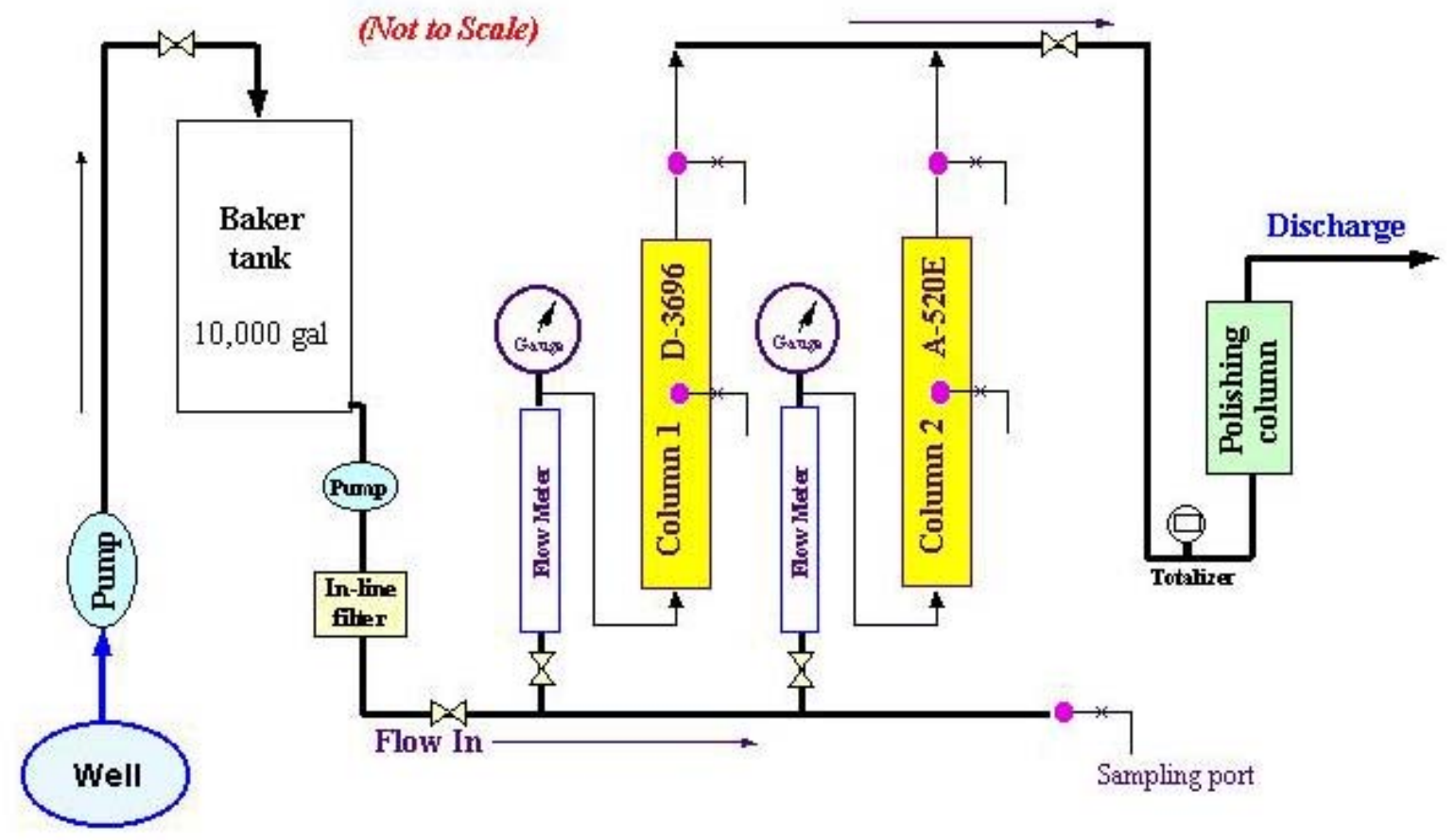

Figure 4. Resin column assembly and flow diagram used for the pilot-scale field experiment at Edwards AFB. Column 1 was packed with the Purolite bifunctional D-3696 resin and the column 2 was packed with the monofunctional A-520E resin. The column dimensions were 2 " in diameter and $\sim 11.5$ " in depth, and the flow rate was set at approximately $500 \mathrm{~mL} / \mathrm{min}$ per column. The influent perchlorate concentration in groundwater was $\sim 400 \mu \mathrm{g} / \mathrm{L}$ throughout the experiment. A polishing column was used to ensure perchlorate capture before discharging the treated water. 


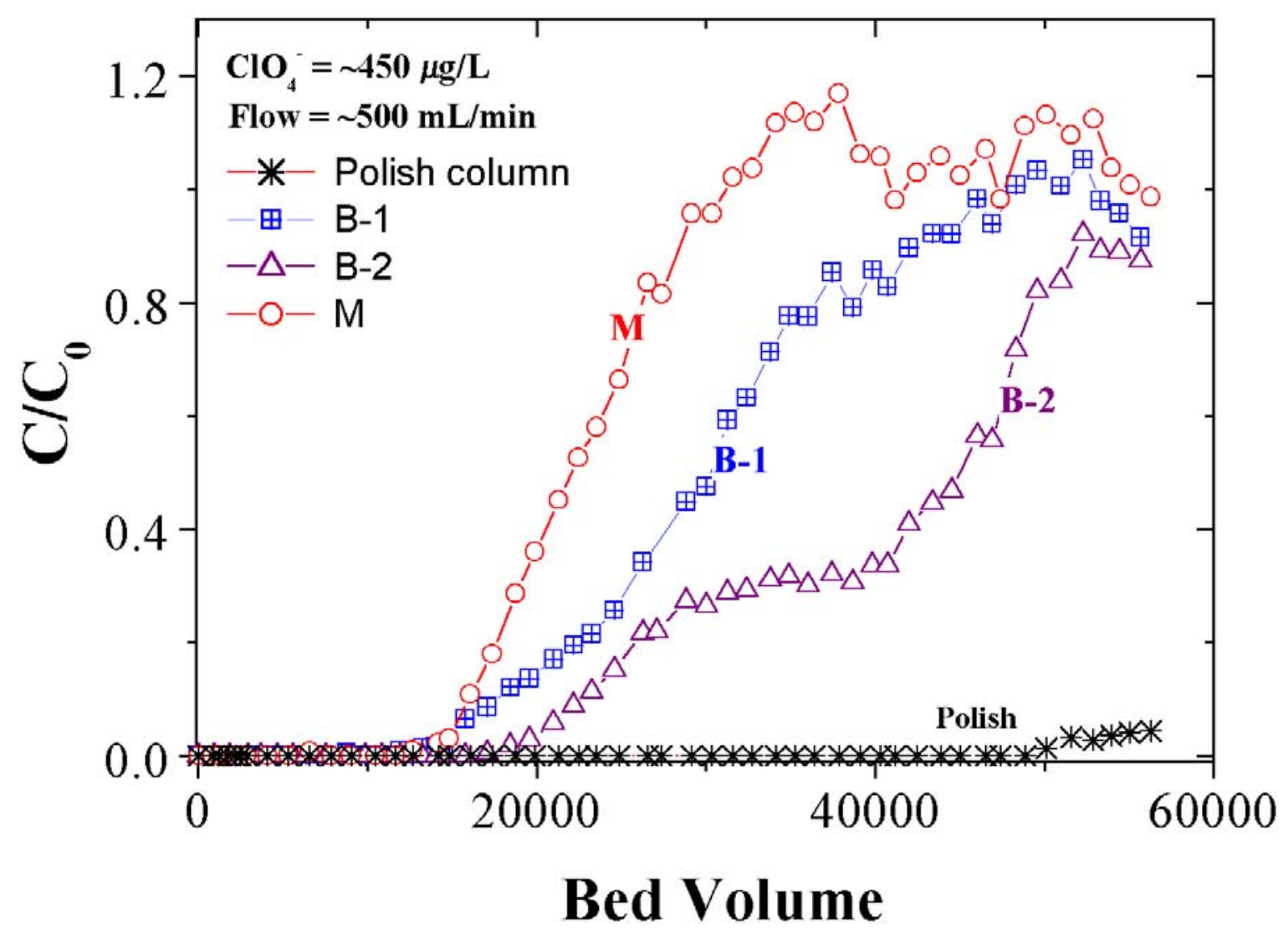

Fig. 5. Breakthrough curves of perchlorate in both the monofunctional (M) and bifunctional (B) resin columns used for groundwater treatment at Edwards AFB. Note: B-1 and B-2 refer to the breakthroughs at the middle and outlet ports of the bifunctional resin bed. Perchlorate breakthrough on the polish column was also plotted. 

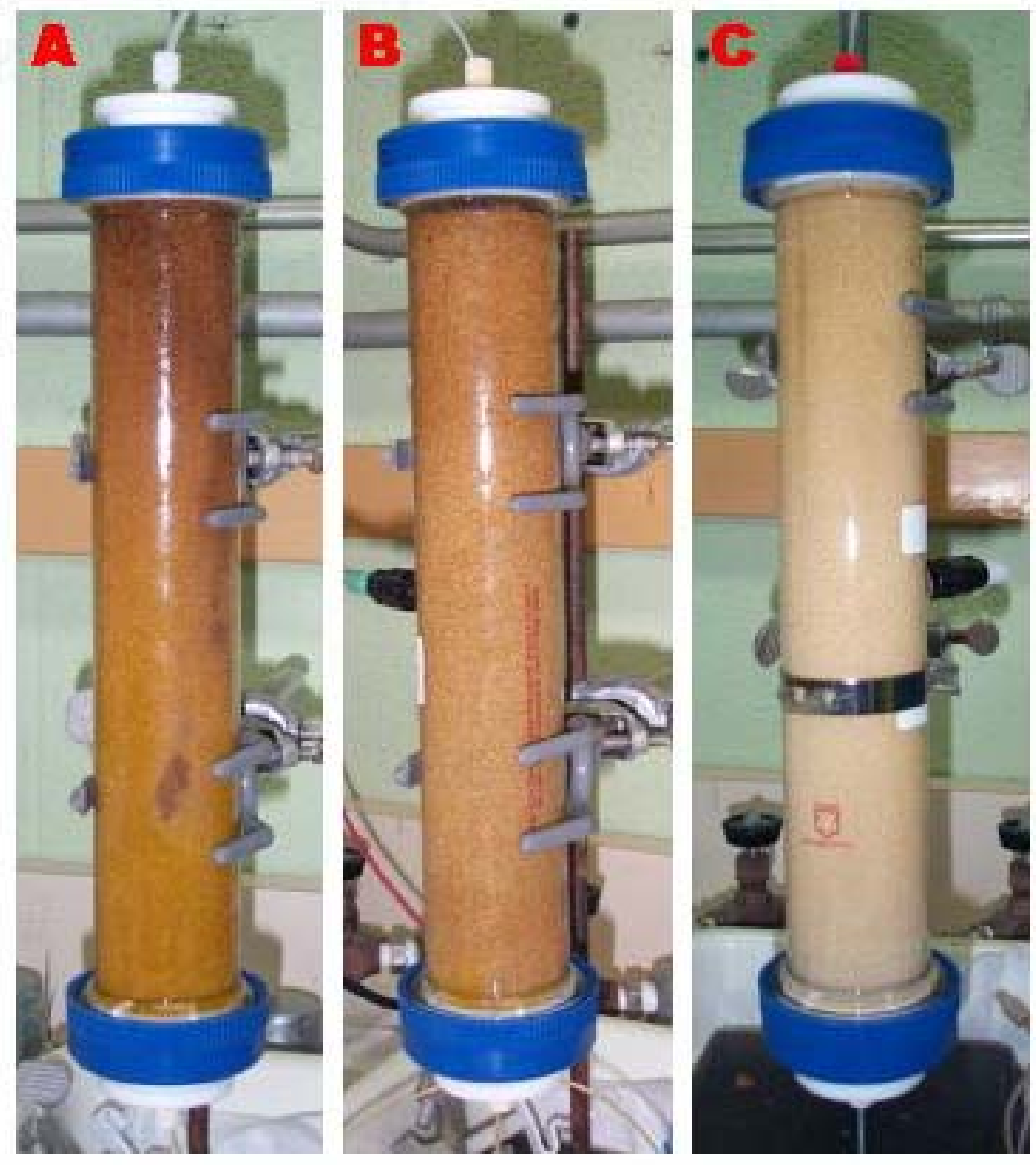

Fig. 6. Fouled resin columns (A and B) as a result of excessive iron oxide precipitation and/or deposition (from the Baker tank) and bio-fouling. Column $\mathrm{C}$ was used in the second run, showing a much lower degree of fouling (used a $1-\mu \mathrm{m}$ in-line filter). 


\subsection{REGENERATION OF RESIN COLUMNS}

Both the bifunctional and monofunctional resin columns were then subjected to regeneration using ORNL's proprietary $\mathrm{FeCl}_{3}-\mathrm{HCl}$ regeneration technique. The regenerant solution was comprised of about $1 \mathrm{M} \mathrm{FeCl}_{3}$ and $4 \mathrm{M} \mathrm{HCl}$. The elution profiles of perchlorate in the regenerant solution are shown in Figure 7. As was observed in the initial bench-scale experiment (Figure 2), we found a rapid desorption of perchlorate from the columns, and the maximum effluent concentrations reached as high as $\sim 8,000 \mathrm{mg} / \mathrm{L}$ for the bifunctional resin and $\sim 6,000 \mathrm{mg} / \mathrm{L}$ for the monofunctional resin column. In comparison with the initial $\mathrm{ClO}_{4}{ }^{-}$concentration in groundwater $(\sim 0.45 \mathrm{mg} / \mathrm{L})$, this is equivalent to a concentration factor of $\sim 18,000$ and $\sim 13,000$ for perchlorate, indicating the effectiveness of the $\mathrm{FeCl}_{3}$ regenerant in stripping off $\mathrm{ClO}_{4}{ }^{-}$from the resin. Nearly $100 \%$ of sorbed $\mathrm{ClO}_{4}{ }^{-}$was stripped off the monofunctional A-520E resin bed after eluting with $\sim 6$ bed volumes of the regenerant solution. However, only about $76 \%$ of sorbed $\mathrm{ClO}_{4}{ }^{-}$was stripped off the bifunctional D-3696 resin bed after $\sim 5$ bed volumes of the regenerant solution had passed through the column (Figure 7). This observation was attributed to the fact that the resin bed was fouled or clogged with iron oxyhydroxides and/or biomass so that part of the exchange sites on the resin bed was not effectively regenerated. This was especially true for the bifunctional resin, which is macroporous and functionalized with large trihexylamine functional groups (Gu et al., 2000). In other words, the bifunctional resin beads are perhaps more susceptible to fouling and clogging than those of the Purolite A-520E resin. Indeed, further experimentation indicated that a nearly $100 \%$ regeneration of the bifunctional resin was achieved when the resin bed was not severely fouled (discussed in the following section).

The regenerated resin beds were washed with dilute $\mathrm{HCl}$ solution $(<0.01 \%)$ and water before they were returned for groundwater treatment. Approximately 20 to 30 bed volumes of dilute acidic washing solution were necessary to rinse off the residual ferric chloride in the resin bed. Analysis of the composite samples indicated that perchlorate was not detected in this acidic washing solution (Table 6), as can be fully expected. Therefore, this acidic washing solution could readily be neutralized with either bicarbonate or hydroxides and be disposed of in situ (e.g., as treated groundwater).

\subsection{RE-EVALUATION OF RESIN PERFORMANCE AND REGENERATION}

After regeneration, both the bifunctional and monofunctional resin beds were returned for continuation of groundwater treatment at Edwards AFB on August 31, 2001. In addition, a fresh bifunctional resin bed was prepared and run in parallel with the two regenerated columns because these two columns were anticipated to perform poorly as a result of the significant fouling that occurred in the previous run. This would also provide another opportunity to assess bifunctional resin performance without the fouling. The flow rate was again set at $\sim 500 \mathrm{~mL} / \mathrm{min}$ for the two regenerated resin columns but was at $\sim 700 \mathrm{~mL} / \mathrm{min}$ for the fresh bifunctional resin bed. A 0.5 $\mu \mathrm{m}$ in-line filter was used to remove most of the particulates and biomass from the Baker tank. Results indeed indicate that, without significant fouling, the fresh bifunctional resin bed (FB, Figure 8) 
Table 6. Analysis of the composite $\mathrm{FeCl}_{3}-\mathrm{HCl}$ regenerant and dilute $\mathrm{HCl}$ washing solutions used for the regeneration of the bifunctional D-3696 resin bed.

\begin{tabular}{cccccccc}
\hline \multirow{2}{*}{ Sample } & $\begin{array}{c}\text { Volume } \\
(\mathrm{L})\end{array}$ & $\begin{array}{c}\mathbf{C l O}_{4}^{-} \\
(\mathrm{mg} / \mathrm{L})\end{array}$ & $\begin{array}{c}\mathbf{A l} \\
(\mathrm{mg} / \mathrm{L})\end{array}$ & $\begin{array}{c}\mathbf{C a} \\
(\mathrm{mg} / \mathrm{L})\end{array}$ & $\begin{array}{c}\mathbf{M g} \\
(\mathrm{mg} / \mathrm{L})\end{array}$ & $\begin{array}{c}\mathbf{M n} \\
(\mathrm{mg} / \mathrm{L})\end{array}$ & $\begin{array}{c}\mathbf{N i} \\
(\mathrm{mg} / \mathrm{L})\end{array}$ \\
\cline { 2 - 7 } Composite 1 & 1.13 & 6450 & 1.09 & 5.84 & 35.1 & 9.81 & 0.80 \\
Composite 2 & 1.01 & 1750 & 0.95 & 0.51 & 50.5 & 6.43 & 0.15 \\
Composite 3 & 0.42 & 150 & 0.71 & 0.33 & 44.8 & 5.17 & 0.10 \\
Composite A & 5.45 & 0 & 0.12 & 0.95 & 74.9 & 2.47 & 0 \\
Composite B & 6.21 & 0 & 0.03 & 0.01 & 0 & 0 & 0 \\
\hline
\end{tabular}

*Results of $\mathrm{Mg}$ and $\mathrm{Mn}$ analyses were subjected to the interference by a high concentration of $\mathrm{Fe}$ in the regenerant solution as analyzed by the atomic absorption spectrometry. 


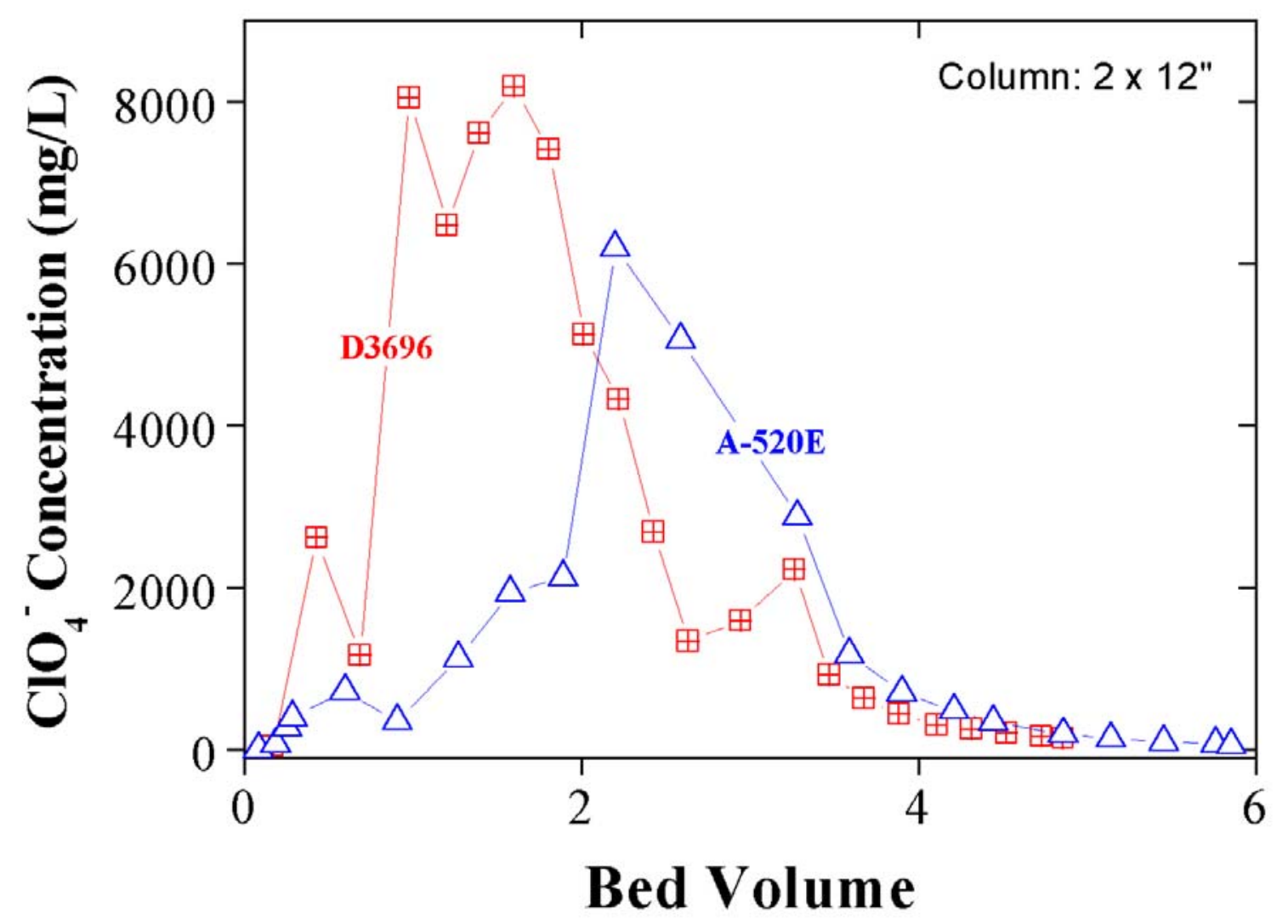

Fig. 7. Perchlorate elution profiles during the regeneration of the bifunctional (D-3696) and monofunctional (A-520E) resin columns used for the pilot-scale field experiment at Edwards AFB. 
performed much better than the same bifunctional resin bed from the previous run (with fouling). Significant breakthrough of perchlorate in this fresh bifunctional resin bed occurred after $\sim 40,000$ bed volumes of groundwater had been treated, despite that a relatively fast flow rate $(\sim 700 \mathrm{~mL} / \mathrm{min})$ was used. Again, in the previous run, the same bifunctional resin bed treated only $\sim 20,000$ bed volumes of groundwater before a significant breakthrough occurred (running at $\sim 500 \mathrm{~mL} / \mathrm{min}$ ) (B, Figure 8).

The two regenerated resin columns performed fairly well (Figure 8) considering the severe fouling that had previously occurred. The regenerated bifunctional resin bed (BR, Figure 8) actually performed somewhat better than its precursor with respect to the initial breakthrough of perchlorate. However, its performance was about 30-40\% lower than that observed on the fresh bifunctional resin bed, which was again attributed to fouling and an incomplete regeneration. Similar results were obtained for the regenerated monofunctional resin bed (MR, Figure 8). From these studies, it is obvious that the effectiveness of regeneration could not be judged solely on the basis of the performance of these two regenerated resin columns.

To further evaluate the regeneration and performance of the bifunctional resin, the fresh bifunctional resin bed used in the second run also was regenerated and re-evaluated. In addition, the monofunctional resin bed was subjected to a second regeneration. The elution profiles of perchlorate in the regenerant solutions of these two columns are shown in Figure 9. Results again indicated a rapid desorption of perchlorate from the column and, with as little as $\sim 2$ bed volumes of regenerant solution passed through the column, $\sim 95 \%$ of sorbed perchlorate was recovered (Figure 9). To our surprise, the maximum effluent $\mathrm{ClO}_{4}{ }^{-}$concentration reached as high as $\sim 60,000 \mathrm{mg} / \mathrm{L}$ or $\sim 600 \mathrm{mM}$. In comparison with the initial $\mathrm{ClO}_{4}{ }^{-}$concentration in groundwater $(\sim 0.45 \mathrm{mg} / \mathrm{L})$, this is equivalent to a concentration factor of $\sim 133,000$ for perchlorate. On the

monofunctional resin bed (second regeneration), the maximum perchlorate concentration reached $\sim 18,000 \mathrm{mg} / \mathrm{L}$, which was also much higher than that observed in the previous run (Figure 7). These observations again demonstrate the effectiveness of the $\mathrm{FeCl}_{3}-\mathrm{HCl}$ regenerant solution in stripping off $\mathrm{ClO}_{4}{ }^{-}$from the Type-I resins that are highly selective for $\mathrm{ClO}_{4}{ }^{-}$sorption.

\section{CONCLUSIONS AND IMPLICATIONS}

A pilot-scale field trial at Edwards AFB demonstrated the effectiveness of using selective anion exchange resins to remove $\mathrm{ClO}_{4}{ }^{-}$from contaminated groundwater and the efficiency of a novel $\mathrm{FeCl}_{3}-\mathrm{HCl}$ regeneration technology (Gu et al., 2001). At an influent $\mathrm{ClO}_{4}{ }^{-}$concentration of $450 \mu \mathrm{g} / \mathrm{L}$, the bifunctional resin was able to treat about 40,000 bed volumes of groundwater (lasting about 4 weeks) before a breakthrough of $\mathrm{ClO}_{4}{ }^{-}$was observed. The spent resin column was successfully regenerated using the $\mathrm{FeCl}_{3}-\mathrm{HCl}$ regenerant solution, and nearly $100 \%$ sorbed $\mathrm{ClO}_{4}{ }^{-}$was recovered with as little as about 2 bed volumes of regenerant solution having passed through the column. Obviously, a combination of selective ion exchange and the $\mathrm{FeCl}_{3}-\mathrm{HCl}$ regeneration technologies are promising in remediating groundwater contaminated with $\mathrm{ClO}_{4}{ }^{-}$ with both a greatly increased treatment efficiency as well as a reduced frequency of resin regeneration compared to the waste brine production and disposal of conventional non-selective ion-exchange 


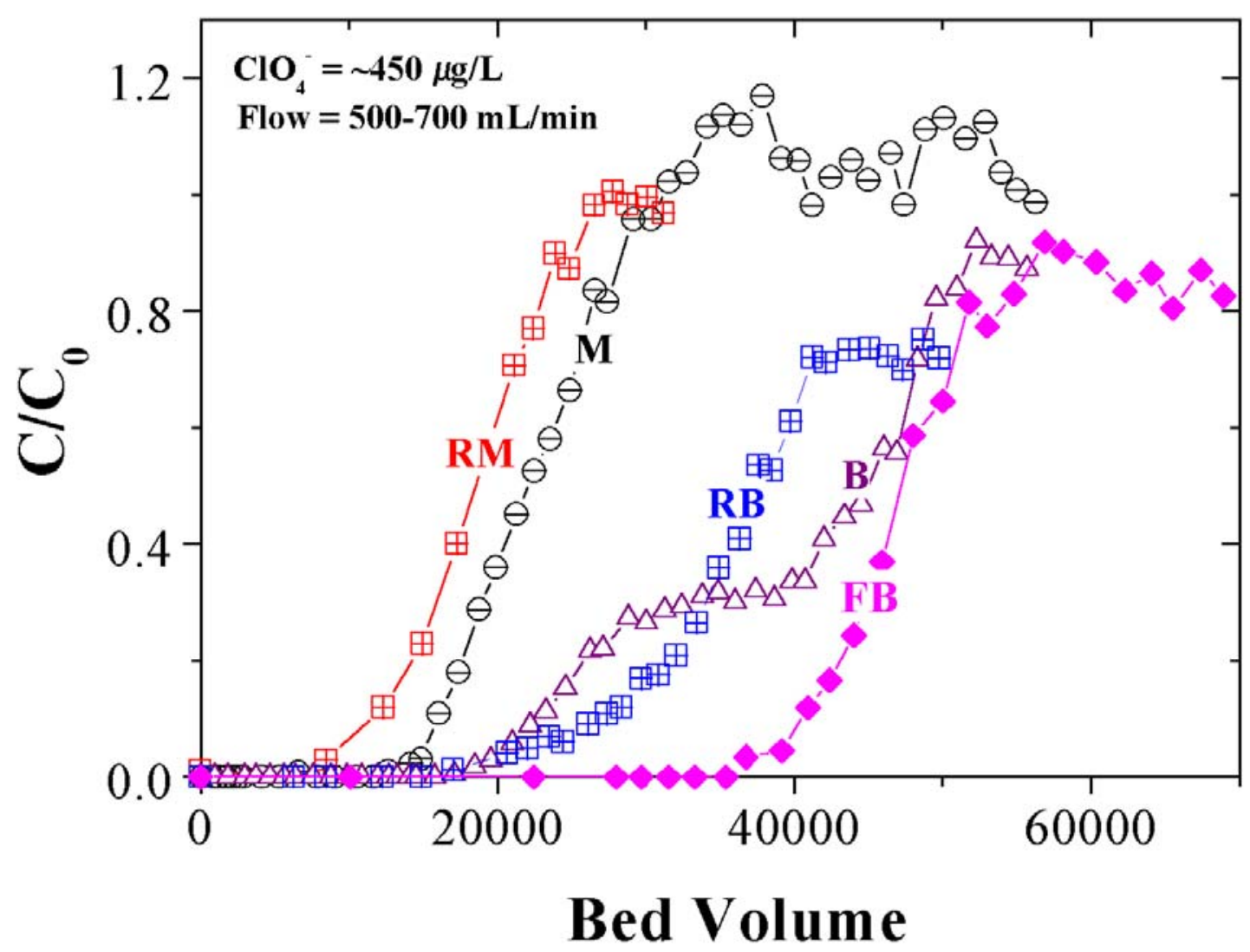

Fig. 8. Breakthrough curves of perchlorate in both the monofunctional $(M)$ and bifunctional $(B)$ resin columns before and after regeneration $(R)$. FB refers to the breakthrough of perchlorate in the fresh bifunctional resin column (without fouling). 


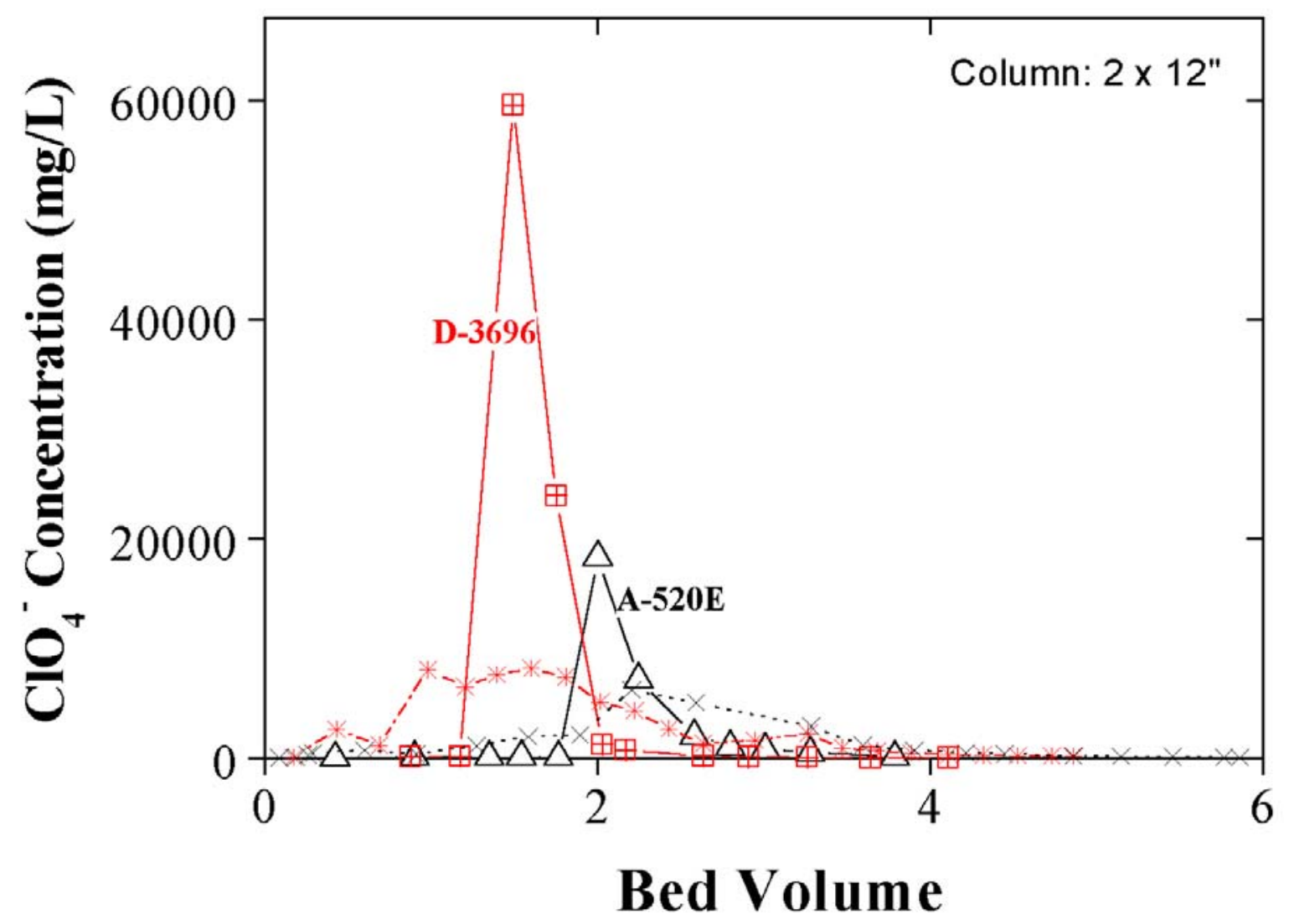

Fig. 9. Perchlorate elution profiles during the regeneration of the unfouled bifunctional resin bed and the second regeneration of the monofunctional resin bed. The dotted lines show the regeneration of those fouled columns for comparison (from Figure 7). 
and regeneration techniques. On the basis that the bifunctional resin was able to treat about 40,000 bed volumes of contaminated groundwater containing $450 \mu \mathrm{g} / \mathrm{L} \mathrm{ClO}_{4}{ }^{-}$(or about 100,000 bed volumes of water containing $50 \mu \mathrm{g} / \mathrm{L} \mathrm{ClO}_{4}{ }^{-}$) ( $\mathrm{Gu}$ et al., 2000a), the waste regenerant production is estimated to be $<0.005 \%$ of the amount of groundwater treated. This is approximately 2 orders of magnitude less than what may be produced by using conventional $\mathrm{NaCl}$ brine regeneration technique (Batista et al., 2000; Brown et al., 2000).

In addition to a significantly reduced secondary waste production, one of the greatest advantages accrued from using selective ion exchange and its regeneration is perhaps the ability to leave the treatment system operating for months in the field before regeneration is needed, minimizing the operational and maintenance cost, as mentioned previously. Of course, duration of the treatment phase will depend on such factors as the influent $\mathrm{ClO}_{4}{ }^{-}$concentration, size of the treatment unit, and flow rate (Gu et al., 2000a). Additionally, only a relatively small treatment unit may be required because the treatment system is highly efficient and can handle a relatively high flow rate (e.g., 1-2 bed volumes per minute). This may translate into a significantly reduced capital cost. As an example, a rough estimate is that a 1000-gpm-treatment unit may cost between $\$ 600,000$ and $\$ 1$ million, which includes the cost of the resin itself, the treatment and regeneration systems, site preparation, and labor. Additional cost savings may also be realized when several 1000-gpm-treatment units are in operation simultaneously so that only one central regeneration facility may be needed for the regeneration and perchlorate-destruction.

By using the $\mathrm{FeCl}_{3}-\mathrm{HCl}$ regeneration technique, additional treatment options are available to completely destroy $\mathrm{ClO}_{4}{ }^{-}$in the regenerant solution so that the spent regenerant solution can be reused or disposed of without the presence of $\mathrm{ClO}_{4}{ }^{-}$as a hazardous component. Recently, a new proprietary methodology also was developed to completely destroy $\mathrm{ClO}_{4}{ }^{-}$in $\mathrm{FeCl}_{3}$ solution at ORNL. Perchlorate was found to decompose into non-hazardous $\mathrm{Cl}^{-}$and water under certain catalytic conditions, and a complete reaction occurs within a few hours to 1 day with an initial $\mathrm{ClO}_{4}{ }^{-}$concentration at about $7,000 \mathrm{mg} / \mathrm{L}$. While perchlorate is completely decomposed, the destruction process does not alter properties of the regenerant solution, so it can be reused. Noting that perchlorate is highly concentrated in the first 2 bed volumes of the $\mathrm{FeCl}_{3}$ regenerant solution (Figure 9), only relatively small volumes of the regenerant solution need to be treated. Therefore, depending on the regulatory requirements and the cost of $\mathrm{ClO}_{4}{ }^{-}$waste disposal, this additional treatment process may have notable economic implications in that not only is a reduced volume of regenerant solution required but also the disposal of hazardous waste regenerant solutions containing $\mathrm{ClO}_{4}{ }^{-}$is eliminated. 


\section{REFERENCES}

Batista, J. R., F. X. McGarvey, and A. R. Vieira. 2000. The removal of perchlorate from waters using ion exchange resins. In Perchlorate in the Environment (eds. E. T. Urbansky) Kluwer/Plenum. New York.

Bonnesen, P.V., G. M. Brown, L. B. Bavoux, D. J. Presley, B. A. Moyer, S. D. Alexandratos, V. Patel, and R. Ober. 2000. Development of bifunctional anion exchange resins with improved selectivity and sorptive kinetics for pertechnetate. 1. Batch-equilibrium experiments. Environ. Sci. Technol. 34:3761-3766.

Brown, G. M., P. V. Bonnesen, B. A. Moyer, B. Gu, S. D. Alexandratos, V. Patel, and R. Ober. $2000 \mathrm{Ch} .15$. The design of selective resins for the removal of pertechnetate and perchlorate from groundwater. In Perchlorate in the Environment (eds. Urbansky, E.T.) Kluwer/Plenum. New York. pp. 155-164

Damian, P. and F. W. Pontius. 1999. From rockets to remediation: the perchlorate problem. Environ. Prot. pp. 24-31.

Gu, B., G. M. Brown, S. D. Alexandratos, R. Ober, J. A. Dale, and S. Plant. 2000a Chapter 16. Efficient treatment of perchlorate $\left(\mathrm{ClO}_{4}^{-}\right)$-contaminated groundwater by bifunctional anion exchange resins. In Perchlorate in the Environment (eds. Urbansky, E.T.) Kluwer/Plenum. New York.

Gu, B., G. M. Brown, P. V. Bonnesen, L. Liang, B. A. Moyer, R. Ober, and S. D. Alexandratos. 2000b. Development of novel bifunctional anion-exchange resins with improved selectivity for pertechnetate sorption from contaminated groundwater. Environ. Sci. Technol. 34:10751080 .

Gu, B., G. M. Brown, L. Maya, and B. A. Moyer. 2001. Regeneration of perchlorate $\left(\mathrm{ClO}_{4}{ }^{-}\right)-$ loaded anion exchange resins by novel tetrachloroferrate $\left(\mathrm{FeCl}_{4}{ }^{-}\right)$displacement technique. Environ. Sci. Technol. 35:3363-3368.

Tripp, A. R. and D. A. Clifford. 2000. The treatability of perchlorate in groundwater using ion exchange technology. In Perchlorate in the Environment (eds. E. T. Urbansky) Kluwer/Plenum. New York.

Urbansky, E. D. 1998. Perchlorate chemistry: Implications for analysis and remediation. Bioremed. J. 2:81-95.

Venkatesh, K. R., S. M. Klara, D. L. Jennings, and N. J. Wagner. 2000 Ch. 14. Removal and destruction of perchlorate and other anions from ground water using the ISEP $+{ }^{\mathrm{TM}}$ system. In Perchlorate in the Environment (eds. Urbansky, E.T.) Kluwer/Plenum. New York. pp. 147153 


\section{INTERNAL DISTRIBUTION}

1. D. T. Bell

2. G. M. Brown

3. T. O. Early

4-8. B. Gu

9. S. G. Hildebrand

\author{
10. Y.-K Ku \\ 11-12. ESD Library \\ 13. ORNL Central Research Library \\ 14 ORNL Laboratory Records-RC
}

\section{EXTERNAL DISTRIBUTION}

15. Todd Battey, Earth Tech, 100 Contractor Road, Edwards, CA 93523.

16. David Campbell, Bldg 9737, MS 8091, Bear Creek Road, National Security Complex, Oak Ridge, TN 37831-8091.

17. Mark Nickerson, Bldg 9737, MS 8091, Bear Creek Road, National Security Complex, Oak Ridge, TN 37831-8091.

18. David Porter, Environmental Management Restoration, AFFTC/EMR, 5 East Popson Ave, Bldg 2650A, Edwards AFB, CA 93524-6225.

19. Andres Rowena, Environmental Management Restoration, AFFTC/EMR, 5 East Popson Ave, Bldg 2650A, Edwards AFB, CA 93524-6225.

20. Paul Schiff, Environmental Management Restoration Branch, AFFTC/EMR, 5 East Popson Ave, Bldg 2650A, Edwards AFB, CA 93524-6225.

21. Andrew J. Shepard, EarthTech, 3327 Longview Dr., Suite 210, North Highlands, CA 95660.

22. James A. Specht, Environmental Management Restoration Branch, AFFTC/EMR, 5 East Popson Ave, Bldg 2650A, Edwards AFB, CA 93524-6225.

23. Robert Wood, Environmental Management Restoration Branch, AFFTC/EMR, 5 East Popson Ave, Bldg 2650A, Edwards AFB, CA 93524-6225. 